\title{
PENGARUH GURU, RAKAN SEBAYA DAN SOKONGAN KELUARGA TERHADAP KETERLIBATAN MATEMATIK DALAM KALANGAN MURID SEKOLAH MENENGAH
}

\author{
${ }^{1}$ Ahmad Fauzi Mohd Ayu, ${ }^{2}$ Aida Suraya Md. Yunus, ${ }^{3}$ Rosnaini Mahmud \\ 1,2,3 Universiti Putra Malaysia \\ 43400 Serdang, Selangor, Malaysia
}

Received : 15 Julai 2017; Accepted : 03 Januari 2018; Published : 25 Jun 2018

\begin{abstract}
Abstrak
Kajian ini bertujuan untuk menentukan pengaruh guru, kesepaduan murid dan penglibatan keluarga terhadap keterlibatan matematik dalam kalangan murid sekolah menengah di Pulau Pinang. Seramai 155 orang murid daripada pelbagai sekolah terlibat dalam kajian yang dijalankan. Dapatan kajian menunjukkan bahawa min keseluruhan keterlibatan murid dalam matematik adalah $3.60(\mathrm{SP}=.41)$. Secara terperinci, keterlibatan murid dalam matematik adalah lebih secara tingkahlaku $(\mathrm{M}=3.76, \mathrm{SP}=0.56)$ diikuti oleh domain afektif $(\mathrm{M}=3.56, \mathrm{SP}=.42)$ dan domain kognitif $(\mathrm{M}=3.55, \mathrm{SP}=0.41)$. Dapatan kajian juga mendapati semasa proses pembelajaran dan pengajaran matematik, murid mendapat sokongan yang baik daripada guru $(\mathrm{M}=3.80$, $\mathrm{SP}=0.56)$, kesepaduan murid $(\mathrm{M}=3.65, \mathrm{SP}=0.53)$ dan penglibatan ibu bapa $(\mathrm{M}=3.32, \mathrm{SP}=0.71)$. Analisis korelasi pula menunjukkan terdapat hubungan signifikan yang positif antara penglibatan ibu bapa $(\mathrm{r}=.515 ; \mathrm{p}<$ $.001)$, sokongan guru $(\mathrm{r}=.494, \mathrm{p}<.001)$ dan kesepaduan murid $(\mathrm{r}=.643$; $\mathrm{p}<.001)$ dengan keterlibatan murid dalam matematik. Analisis regresi berganda pula menunjukkan bahawa ketiga-tiga faktor di kaji mempengaruhi keterlibatan murid dalam matematik dengan varian sebanyak 46.2\%. Kajian ini jelas menunjukkan bahawa ketiga-tiga faktor ini dapat meningkatkan keterlibatan murid dalam matematik dengan kesepaduan murid merupakan penyumbang terbesar iaitu sebanyak $42.5 \%$.
\end{abstract}

Kata kunci Keterlibatan matematik, penglibatan ibubapa, kesepaduan murid dan sokongan guru.

\begin{abstract}
The purpose of this study is to identify the influence of teachers support, students' cohesiveness and parental involvement toward mathematics engagement among secondary school students in Pulau Pinang. A total of 155 students from various schools were involved in the study. The finding of this study showed that overall mean for students' mathematics engagement is $3.60(\mathrm{SD}=.41)$. In detail, students' engagement in mathematics is more towards behavior $(\mathrm{M}=3.76, \mathrm{SD}=0.56)$ followed by affective domain $(\mathrm{M}$ $=3.56, \mathrm{SD}=.42)$ and cognitive domain $(\mathrm{M}=3.55, \mathrm{SD}=0.41)$. Research findings also found out that during mathematics teaching and learning process, pupils received good support from teachers $(\mathrm{M}=3.80, \mathrm{SD}=0.56)$, students'
\end{abstract}


cohesiveness $(\mathrm{M}=3.65, \mathrm{SD}=0.53)$ and parental involvement $(\mathrm{M}=3.32$, $\mathrm{SD}=0.71)$. Meanwhile, correlation analysis indicated that there is positive significant relationship between parental involvement $(\mathrm{r}=.515 ; \mathrm{p}<.001)$, teacher support $(\mathrm{r}=.494, \mathrm{p}<.001)$ and students' cohesiveness $(\mathrm{r}=.643 ; \mathrm{p}<$ .001 ) with students' engagement in mathematics. Multiple regression analysis shows that these three variables studied influences students' engagement in mathematics engagement with variance of $56.2 \%$. This study clearly showed that these three factors could increase students' engagement in mathematics with students' cohesiveness is the highest contributor with $42 \%$.

Keywords

Mathematics engagement, parental involvement, students' cohesiveness and teacher support.

\section{PENGENALAN}

Keterlibatan murid adalah satu komoditi berharga bukan sahaja kepada guru tetapi juga kepada murid. Di sekolah, murid lebih seronok apabila mereka terlibat dengan aktiviti kelas. Keterlibatan murid semasa di sekolah banyak membantu menyiapkan murid bagi menghadapi cabaran kerja serta menggalakkan daya tahan motivasi mereka (Martin \& Marsh, 2009). Bagi jangka panjang pula, keterlibatan murid merupakan faktor peramal kepada pembelajaran dan pencapaian murid, selain daripada dapat menamatkan pengajian daripada sekolah dan seterusnya dapat memasuki serta berjaya pada peringkat kolej (Fredricks, Blumenfeld, \& Paris, 2004).

Keterlibatan murid merujuk kepada penglibatan murid dan secara berkesan samada dalam atau luar kelas yang membawa kepada pelbagai hasil yang boleh diukur (Kuh, 2007). Newmann, Wehlage dan Lamborn (1992) mentakrifkan keterlibatan sebagai satu bentuk psikologi murid dan usaha ini ditumpukan ke arah pembelajaran, pemahaman, atau penguasaan ilmu pengetahuan serta dapat meningkatkan hasil kerja akademik. Para pengkaji melihat keterlibatan sebagai satu konstruk yang pelbagai walaupun banyak kajian lepas hanya merujuk kepada satu dimensi sahaja. Namun begitu, penyelidikan berkaitan keterlibatan murid menunjukkan ia merupakan satu konstruk yang sangat kompleks dan pelbagai. Antaranya adalah Connell (1990) dan Connell dan Wellborn (1991) yang memperkenalkan satu model komprehensif keterlibatan yang terdiri daripada aspek kognitif, tingkah laku dan emosi. Keterlibatan kognitif melibatkan kemampuan murid mengembangkan idea, menghayati nilai pembelajaran dan kesediaan mereka untuk menjangkaui keperluan minimum (Fredicks et. al 2004). Keterlibatan tingkah laku merujuk kepada penglibatan murid dalam pembelajaran dan aktiviti kelas (Skinner \& Belmont, 1993; Willms, 2003; Finn \& Zimmer, 2012). Ini termasuk mematuhi peraturan tingkah laku, mengikuti mata pelajaran seperti yang dikehendaki dan hadir ke kelas tepat pada masa (Fredericks \& McColskey, 2012). Keterlibatan afektif pula merujuk kepada reaksi murid terhadap sekolah, guru, rakan dan ahli akademik yang mempengaruhi kesediaan mereka untuk melibatkan diri dalam aktiviti sekolah (Fredicks, et. al 2004), sikap atau perasaan berkaitan usaha mereka dalam pembelajaran (Skinner \& Belmont, 1993), perasaan, 
nilai, reaksi terhadap aktiviti pembelajaran dan guru serta rasa ingin tahu lebih (Blumenfeld et. al., 2005), kegelisahan, minat, kebosanan, orientasi pencapaian dan kekecewaan dalam pembelajaran (Connell \& Wellborn, 1999; Kong, et. al, 2003).

Kajian lepas juga telah mengaitkan pelbagai faktor dengan keterlibatan murid. Terdapat pelbagai faktor yang dilihat mempengaruhi tahap keterlibatan murid dalam matematik pada tahun-tahun pertengahan adalah peralihan kepada persekolahan menengah, pengaruh rakan sebaya, amalan pedagogi yang digunakan dalam bilik darjah matematik dan pengaruh guru (Attard, 2011). Sokongan guru semasa dalam proses pembelajaran dan pengajaran dalam kelas adalah penting bagi meningkat keterlibatan murid. Hubungan yang berkualiti antara guru dan murid pada peringkat awal persekolahan memberi implikasi terhadap masa depan akademik murid, sosial dan tingkah laku (Hughes et al., 2001; Pianta \& Stuhlman, 2004). Hubungan positif antara guru dan murid juga dikaitkan dengan rasa kehadiran dan keakraban, kehangatan antara kedua-duanya (Hamre \& Pianta, 2001). Murid yang merasa seronok akan hubungan rapat dengan guru lebih terlibat di mana mereka akan bekerja keras dalam kelas, tabah semasa menghadapi kesukaran, menerima arahan dan kritikan guru, lebih baik mengawal tekanan dan memberi tumpuan lebih kepada guru (Little \& Kobak, 2003; Midgley; Ridley, McWilliam, \& Oates, 2000). Dalam erti kata lain, murid lebih berminat dalam pembelajaran sekiranya mereka merasakan guru mengambil berat dan berminat terhadap pembelajaran mereka (Goodenow, 1993). Selain itu, sokongan guru mempunyai hubungan positif dengan keterlibatan murid terutamanya semasa mengambil bahagian dalam aktiviti sekolah (Battistich, Solomon, Watson, \& Schaps 1997; Wang \& Holcombe 2010). Kajian oleh Tas (2016) mendapati murid yang merasakan guru sains lebih berminat dengan murid dan membantu mereka apabila menghadapi masalah mempunyai hubungan positif yang signifikan dengan keterlibatan murid dari aspek kognitif, tingkah laku, afektif dan agentik.

Rakan sebaya pula merujuk kepada satu unit sosial yang diwujudkan untuk berkongsi nilai dan pelakuan yang sama serta struktur sosial antara pemimpin dengan pengikut (Berk, 1997). Pada kebiasaannya, remaja memilih rakan sebaya yang mempunyai persamaan tingkah laku, sikap dan identiti dengan mereka (Akers, Jones \& Coyle, 1998; Hogue \& Steinberg, 1995). Penglibatan rakan sebaya juga dilihat antara faktor yang mempengaruhi keterlibatan murid dalam kelas dan pencapaian akademik pelajar. mKajian oleh Steinberg et al. (1996) menunjukkan bahawa rakan sebaya boleh mendorong seseorang pelajar untuk berusaha dan terlibat sepenuhnya dengan akademik untuk berjaya. Namun begitu terdapat juga kajian lepas yang mendapati bahawa penglibatan rakan sebaya tidak mempengaruhi keterlibatan pelajar (Furrer \& Skinner, 2003). Sementara itu, pengkaji seperti Veiga, Galvao dan Almeida (2012), serta Juvonen, Espinoza dan Knifsend (2012) mendapati terdapat hubungan positif antara faktor pengaruh rakan sebaya dengan keterlibatan murid dalam kelas.

Penglibatan keluarga atau ibu bapa merujuk kepada sikap dan tingkah laku ibu bapa yang bertujuan untuk mempengaruhi pendidikan anak mereka (Christenson, 2004). Penglibatan ibu bapa ditarifkan sebagai sikap dan perlakuan keluarga yang mempengaruhi pendidikan anak (Fantuzzo, Tighe, \& Childs, 2000; Oyserman, 
Brickman; Rhodes, 2007) dan konstruk dua arah ini ditunjukkan sebagai hubungan yang lebih jelas dengan kemenjadian anak-anak (Christenson, 2004). Kajian oleh Amold, Zeljo dan Doctoroff (2008) menunjukkan peranan ibubapa merupakan elemen utama dalam kemajuan murid. Begitu juga kajian oleh Gibson dan Jefferson (2006) mendapati penglibatan keluarga dapat membantu murid mendapat gred yang tinggi melalui pemantauan aktiviti harian dan progres sekolah. Ini memandangkan keluarga dapat mempengaruhi komitmen anak-anak untuk ke sekolah dengan melalui sokongan akademik dan memberi motivasi untuk mereka belajar (Morse, Christenson \& Lehr, 2004).

Pencapaian matematik dalam kalangan murid di Malaysia sering kali diperkatakan sejak kebelakangan ini. Ini dilihat berdasarkan kepada keputusan peperiksaan Trends in International Mathematics and Science Study (TIMSS) dan Programme for International Student Assessment (PISA) yang menunjukkan penurunan yang ketara. Selain daripada ketidak upayaan murid dalam aspek kemahiran berfikir aras tinggi, faktor murid juga perlu di kaji seperti faktor keterlibatan matematik murid dalam kelas. Semasa proses pembelajaran dan pengajaran dalam kelas matematik, murid yang gagal memberi penumpuan ataupun tidak melibatkan diri dalam aktiviti kelas sering dikaitkan dengan ketinggalan ataupun kegagalan memperolehi markah yang baik dalam matematik. Malahan faktor yang mempengaruhi keterlibatan matematik murid juga perlu dilakukan dari semasa ke semasa bagi membolehkan tindakan dilakukan membantu murid dalam matematik.

\section{OBJEKTIF KAJIAN}

Kajian ini dijalankan bagi menentukan faktor yang mempengaruhi keterlibatan matematik (afektif, kognitif dan tingkahlaku) dalam kalangan murid Tingkatan 4 di Pulau Pinang.

Secara khusus, kajian ini bertujuan untuk menentukan:

1. Keterlibatan murid dalam matematik (afektif, kognitif dan tingkahlaku) dalam kalangan murid sekolah menengah.

2. Penglibatan ibu bapa dalam kalangan murid sekolah menengah.

3. Sokongan guru dalam kalangan murid sekolah menengah.

4. Penglibatan sebaya dalam kalangan murid sekolah menengah.

5. Hubungan penglibatan ibubapa, sokongan guru dan kesepaduan rakan sebaya dengan keterlibatan murid dalam matematik dalam kalangan murid sekolah menengah.

6. Faktor yang mempengaruhi keterlibatan murid dalam matematik (afektif, kognitif dan tingkahlaku) dalam kalangan murid sekolah menengah.

\section{METODOLOGI KAJIAN}

Kajian ini dijalankan menggunakan reka bentuk kajian tinjauan yang merangkumi pelbagai jenis sekolah di seluruh Malaysia. Reka bentuk kajian tinjauan merupakan 
kaedah yang terbaik bagi mengukur pelbagai jenis data yang tidak boleh diperhatikan (Bhattacherjee, 2012). Pengkaji menggunakan kaedah pensampelan bertujuan yang terdiri daripada 50 orang murid tingkatan 4 yang dipilih secara rawak daripada pelbagai jenis sekolah di Pulau Pinang. Seramai 155 murid tingkatan 4 yang berkebolehan sederhana dalam matematik di setiap sekolah terpilih.

Dalam kajian ini pengkaji menggunakan soal selidik sebagai instrumen kajian bagi mendapatkan maklumat daripada responden. Instrumen kajian adalah terdiri daripada lima bahagian iaitu bahagian A bagi mengukur demografi responden. Bahagian B pula bertujuan mengukur maklumat mengenai keterlibatan murid dalam matematik. Bagi tujuan itu, penyelidik telah mengadaptasikan 57 item daripada Kong, Wong dan Lam (2003). Keterlibatan murid dalam matematik terdiri daripada tiga domain iaitu afektif, kognitif dan tingkah laku. Bagi tujuan analisis, mean skor dibahagikan kepada tiga bahagian iaitu (1) keterlibatan rendah bagi nilai min antara 1 hingga 2.33; (2) keterlibatan sederhana bagi nilai min antara 2.34 hingga 3.67 dan (3) keterlibatan tinggi bagi nilai min antara 3.68 hingga 5.00 .

Bahagian $\mathrm{C}$ akan mengukur penglibatan ibu bapa terdiri daripada tujuh item. Dalam pada itu, tujuh item juga digunakan bagi mengukur sokongan guru (bahagian D) dan kesepaduan pelajar (bahagian E) masing-masing. Item bahagian C, D dan E adalah di adaptasikan daripada instrumen kajian oleh Aldridge dan Fraser (2000) dan Dorman (2003). Item Bahagian B, C, D dan E diukur berdasarkan skala likert -5 iaitu Sangat tidak setuju (1), Tidak Setuju (2), Tidak pasti (3), Setuju (4) dan Sangat Setuju (5).

Satu kajian rintis telah dijalankan ke atas 50 orang murid di salah sebuah sekolah menengah harian bagi mengukur nilai keboleh percayaan instrumen kajian. Bagi keterlibatan matematik, nilai cronbach alpha adalah .849 bagi keterlibatan kognitif, keterlibatan afektif (.833) dan keterlibatan perlakuan (.832). Sementara itu, nilai Cronbach Alpha bagi mengukur sokongan guru adalah .878, kesepaduan rakan sebaya (.816) dan penglibatan ibu bapa pula adalah .834. Menurut DeVillis (2016) dan Sekaran (1992), nilai cronbach alpha melebihi 0.7 boleh di guna pakai. Justeru, instrumen kajian boleh di terima memandangkan nilai cronbach alpha adalah melebihi 0.7 .

\section{DAPATAN KAJIAN}

Perbincangan dapatan kajian ini menjurus kepada objektif kajian. Seramai 155 orang responden terlibat dalam kajian yang terdiri daripada 82 murid lelaki $(52.9 \%)$ dan 73 murid perempuan (47.1\%). Daripada jumlah itu, 76 orang murid (49 \%) terdiri daripada bangsa Melayu diikuti 54 orang (34.8\%) bangsa Cina, 24 orang murid (15.5 \%) bangsa India dan seorang adalah Orang Asli.

Pemboleh ubah bersandar dalam kajian ini adalah keterlibatan murid dalam matematik. Ia berlaku apabila murid merasakan bahawa matematik adalah mata pelajaran yang menyeronokkan, menghargai pembelajaran matematik dan melihat kepentingannya dalam kehidupan dan pada masa depan serta melihat hubungan di antara matematik yang mereka pelajari di sekolah dengan penggunaannya di luar sekolah (Attard, 2012). Dalam kajian ini, keterlibatan murid dalam matematik merangkumi 
keterlibatan afektif, keterlibatan tingkah laku dan keterlibatan kognitif. Keterlibatan afektif merujuk kepada reaksi murid dalam bilik darjah sewaktu proses pengajaran dan pembelajaran matematik di jalankan, sikap murid terhadap guru matematik dan rakan sebaya serta rasa ingin tahu. Sementara itu, keterlibatan tingkah laku pula merangkumi kelakuan positif yang terdiri daripada tingkah laku yang menggambarkan usaha, ketekunan, tumpuan, pencapaian, menyumbang kepada perbincangan kelas dan melengkapkan tugasan semasa proses pembelajaran dan pengajaran matematik. Akhir sekali, keterlibatan kognitif mengukur kecerdasan, kebolehan mental, kegigihan melakukan tugasan, keprihatinan, komunikasi, persepsi dan pengalaman semasa proses pembelajaran dan pengajaran matematik. Min keseluruhan bagi keterlibatan matematik responden adalah $3.60(\mathrm{SP}=.41)$ (rujuk Jadual 1). Ini menunjukkan responden mempunyai keterlibatan matematik dalam proses pembelajaran dan pengajaran matematik pada aras sederhana. Dari segi pecahan mengikut dimensi, min tertinggi merujuk kepada keterlibatan tingkah laku pada aras tinggi $(\mathrm{Min}=3.76$; $\mathrm{SP}$ $=.56$ ). Sementara itu, dua lagi dimensi keterlibatan berada pada aras sederhana iaitu keterlibatan afektif $(\mathrm{Min}=3.56, \mathrm{SP}=.42)$ dan keterlibatan kognitif $(\mathrm{Min}=3.55, \mathrm{SP}$ $=.41$ ). Secara keseluruhan, keterlibatan murid dalam matematik adalah baik sama ada secara keseluruhan mahupun bagi setiap dimensi yang mengukur keterlibatan matematik murid.

Dalam kajian ini, sebanyak tiga pemboleh ubah kajian iaitu penglibatan ibu bapa, kesepaduan murid dan sokongan guru dikaji bagi menentukan pengaruh terhadap keterlibatan matematik. Penglibatan ibu bapa memberi implikasi terhadap amalan dengan menyediakan sokongan empirikal untuk mewujudkan persekitaran sekolah yang boleh memberikan semangat kepada anak serta mewujudkan suasana keterlibatan dalam kelas. Min keseluruhan bagi penglibatan ibu bapa adalah $3.32(\mathrm{SP}=.71)$ (rujuk Jadual 1). Sokongan guru pula merujuk sejauh mana guru dapat membantu, menjadi rakan, percaya dan berminat dengan murid. Min keselurhan bagi sokongan guru adalah 3.81 dengan sisihan piawai adalah .56. Akhir sekali, kesepaduan murid pula merujuk kepada sejauh mana responden tahu, membantu dan menyokong rakan antara satu sama lain. Min keseluruhan bagi kesepaduan murid adalah 3.65 dengan sisihan piawai adalah .53 .

Jadual 1 Min dan sisihan piawai bagi pemboleh ubah kajian

\begin{tabular}{lccc}
\hline & & Min & SP \\
\hline Keterlibatan matematik & kognitif & 3.55 & .41 \\
& kelakuan & 3.76 & .56 \\
& afektif & 3.56 & .42 \\
\cline { 2 - 4 } & keseluruhan & 3.60 & .41 \\
\cline { 2 - 4 } Penglibatan ibu bapa & & 3.32 & .71 \\
Sokongan guru & & 3.81 & .56 \\
Kesepaduan murid & & 3.65 & .53 \\
\hline
\end{tabular}

Jadual 2 menunjukkan pekali korelasi Pearson antara pemboleh ubah tak bersandar (penglibatan ibu bapa, sokongan guru dan kesepaduan murid) dengan pemboleh ubah 
bersandar (keterlibatan murid dalam matematik). Analisis menunjukkan terdapat hubungan positif antara penglibatan ibu bapa $(\mathrm{r}=.515 ; \mathrm{p}<.001)$, sokongan guru $(\mathrm{r}=$ $.494, \mathrm{p}<.001)$ dan kesepaduan rakan sebaya $(\mathrm{r}=.643 ; \mathrm{p}<.001)$ dengan keterlibatan murid dalam matematik. Ini menunjukkan bahawa dengan penglibatan ibu bapa dalam membantu anak mereka terutama dalam matematik dapat membina keterlibatan murid dalam matematik. Guru yang menunjukkan sokongan yang kuat terhadap murid juga dapat meningkatkan keterlibatan murid dalam matematik. Akhir sekali, penglibatan rakan sebaya semasa kelas matematik juga dapat meningkatkan keterlibatan matematik murid.

Jadual Pekali korelasi Pearson hubungan antara penglibatan ibu bapa, sokongan guru dan kesepaduan rakan sebaya dengan keterlibatan murid dalam matematik

\begin{tabular}{|c|c|c|c|c|}
\hline & & $\begin{array}{c}\text { Penglibatan } \\
\text { ibu bapa }\end{array}$ & Sokongan guru & $\begin{array}{c}\text { kesepaduan } \\
\text { rakan sebaya }\end{array}$ \\
\hline \multirow{2}{*}{$\begin{array}{c}\text { keterlibatan murid } \\
\text { dalam matematik }\end{array}$} & $\mathrm{r}$ & $.515^{* *}$ & $.494 * *$ & $.643^{* *}$ \\
\cline { 2 - 5 } & Sig (2 tailed) & & & \\
\hline
\end{tabular}

Analisis regresi pelbagai di jalankan untuk meramal faktor (penglibatan ibu bapa, sokongan guru dan penglibatan rakan sebaya) yang mempengaruhi keterlibatan murid dalam matematik. Andaian untuk normailiti, lineariti, homoscedasticity dan independence of residuals telah dipatuhi. Jadual 3 menunjukkan bahawa semua faktor yang dikaji menyumbang sebanyak 46.2\% (adjusted $R$ square) varians terhadap keterlibatan matematik murid.

Jadual 3 Ringkasan Model regresi

\begin{tabular}{cccc}
\hline $\mathrm{R}$ & $\mathrm{R}$ Square & Adjusted R Square & Std. Error of the Estimate \\
\hline $.689 \mathrm{~b}$ & 0.475 & 0.462 & 0.29179 \\
\hline
\end{tabular}

Pembolehubah bersandar: keterlibatan murid dalam matematik

Pemalar : penglibatan ibu bapa, sokongan guru dan kesepaduan rakan sebaya

Hasil analisis regresi ANOVA menunjukkan hubungan linear yang signifikan antara pembolehubah bebas dengan pembolehubah bersandar $\left.\left(\mathrm{F}_{3,131}\right)=38.537, \mathrm{p}=0.000\right)$.

Jadual 4 Analisis regresi ANOVA

\begin{tabular}{|l|c|c|c|c|c|}
\hline & Sum of Squares & df & Mean Square & F & Sig. \\
\hline Regression & 9.843 & 3 & 3.281 & 38.537 & .000 \\
\hline Residual & 10.898 & 128 & 0.085 & & \\
\hline Total & 20.741 & 131 & & & \\
\hline
\end{tabular}

Model anggaran bagi coefficiants (rujuk Jadual 5) menunjukkan pembolehubah peramal yang mempengaruhi keterlibatan matematik ialah kesepaduan rakan sebaya dengan nilai Beta $(\beta)$ yang tertinggi iaitu 0.425 diikuti oleh penglibatan ibu bapa $(\beta=.267)$ dan sokongan guru $(\beta=.162)$. Persamaan analisis regresi adalah seperti berikut.

$$
=.334 x_{1}+.116 x_{2}+.151 x_{3}+1.428
$$


Berdasarkan nilai tersebut dapat di rumuskan bahawa kesepaduan murid merupakan faktor terpenting dalam mempengaruhi keterlibatan murid dalam matematik.

Jadual 5 Model anggaran bagi coefficiants

\begin{tabular}{|c|c|c|c|c|c|}
\hline & \multicolumn{2}{|c|}{ Unstandardized Coefficients } & \multirow{2}{*}{$\begin{array}{c}\text { Standardized } \\
\text { Coefficients } \\
\text { Beta }\end{array}$} & \multirow[t]{2}{*}{$\mathrm{t}$} & \multirow[t]{2}{*}{ Sig. } \\
\hline & B & Std. Error & & & \\
\hline (Constant) & 1.428 & 0.207 & & 6.899 & .000 \\
\hline kesepaduan rakan sebaya & 0.334 & 0.064 & 0.425 & 5.195 & .000 \\
\hline Sokongan guru & 0.116 & 0.056 & 0.162 & 2.055 & 0.042 \\
\hline Penglibatan ibu bapa & 0.151 & 0.04 & 0.267 & 3.811 & .000 \\
\hline
\end{tabular}

\section{PERBINCANGAN}

Mempelajari matematik pada peringkat sekolah adalah sesuatu yang penting terutamanya murid yang mengikuti aliran sains dan teknik vokasional. Kefahaman dan kemahiran yang baik dalam matematik banyak membantu murid apabila melanjutkan pelajar pada peringkat lebih tinggi terutamanya apabila mengikuti pengajian dalam aliran sains. Namun begitu, tidak boleh dinafikan bahawa aliran lain pun memerlukan kefahaman dan kemahiran tinggi dalam matematik. Pelbagai faktor dikaitkan dengan pencapaian matematik murid. Antaranya adalah faktor keterlibatan matematik murid semasa pengajaran dan pembelajaran matematik dalam kelas. Kajian yang dijalankan menunjukkan bahawa keterlibatan matematik secara keseluruhan berada pada aras sederhana. Ini memberi gambaran bahawa usaha yang lebih perlu dilakukan bagi mempastikan murid sekolah ini lebih terlibat dalam matematik semasa proses pengajaran dan pembelajaran. Ini disebabkan keterlibatan murid dalam matematik dikaitkan dengan kualiti tinggi dalam hasil pembelajaran (Krause \& Coates, 2008). Malahan, keterlibatan murid dalam matematik adalah penting dan memberi kelebihan dari aspek kompetensi akademik, pencapaian serta pembelajaran efektif (Harris, 2008; Lewis, 2010; Li et al. 2010; Park, 2005; Wang \& Eccles, 2012).

Kajian ini juga menunjukkan murid mempunyai keterlibatan matematik yang tinggi dari aspek tingkah laku. Ini memberi implikasi bahawa murid telah menunjukkan usaha yang tinggi, ketabahan serta penglibatan secara aktif dalam aktiviti matematik apabila tugasan matematik dilihat sebagai sukar. Namun begitu bagi keterlibatan murid dalam matematik dari segi afektif dan kognitif berada pada tahap sederhana. Guru matematik perlu memainkan peranan penting bagi menanam unsur positif kepada murid dalam matematik. Andaian yang menyatakan matematik adalah sukar, membosankan, serta tidak penting perlu di atasi bagi membolehkan mereka merasakan kepentingan matematik tersebut. Apabila murid merasakan matematik itu sesuatu yang menyeronokkan serta penting untuk mereka kuasai dapat membantu meningkatkan keterlibatan afektif murid. Selain itu, pendekatan pengajaran yang memungkinkan murid sukar untuk memahami dan menguasai matematik perlu diubah bagi membantu meningkatkan keterlibatan matematik murid dari aspek kognitif. Murid perlu diberi peluang sama rata untuk melibatkan diri dengan aktiviti matematik 
semasa proses pengajaran dan pembelajaran matematik bagi membantu meningkatan keterlibatan matematik murid dalam semua dimensi tersebut. Kajian oleh Gunuc (2014) menunjukkan bahawa keterlibatan dari aspek kognitif, tingkah laku dan afektif merupakan faktor peramal kepada pencapaian murid.

Kajian berkaitan keterlibatan tidak seharusnya menjurus kepada keterlibatan murid semata-mata tetapi juga faktor yang mempengaruhi keterlibatan murid juga perlu dikenal pasti. Dalam kajian ini, tiga faktor yang di kaji iaitu penglibatan rakan sebaya, sokongan guru, dan penglibatan ibu bapa. Dapatan kajian menunjukkan ketiga-tiga faktor yang dikaji itu mempengaruhi keterlibatan murid dalam matematik. Namun begitu, penglibatan rakan sebaya dilihat memberi sumbangan paling tinggi terhadap keterlibatan murid dalam matematik. Dapatan kajian lepas juga menunjukan terdapat hubungan antara sokongan guru dengan keterlibatan murid (Battistich, Solomon, Watson, \& Schaps 1997; Wang \& Holcombe 2010; Tas, 2016). Kajian juga mendapati terdapat hubungan antara kesepaduan rakan sebaya dengan keterlibatan murid (Steinberg et al., 1996; You, 2011; Veiga, Galvao \& Almeida, 2012; Juvonen, Espinoza \& Knifsend, 2012). Begitu juga kajian oleh Amold, Zeljo dan Doctoroff (2008) serta Gibson dan Jefferson (2006) yang mendapati penglibatan ibu bapa juga mempunyai hubungan dengan keterlibatan murid.

\section{RUJUKAN}

Aldridge, J. M. \& Fraser, B. J. (2000) A cross-cultural study of classroom learning environments In Australia and Taiwan. Learning Environments Research, 3, 101134.

Akers, J. F., Jones, R., \& Coyl, D. D. (1998). Adolescent friendship pairs: Similarities in identity status development, behaviors, attitudes, and intentions. Journal of Adolescent Research, 13, 178-201.

Arnold, d. H., zeljo, A. \& doctoroff, g. 1. 2008. Parent involvement in preschool: Predictors and the relation of involvement to pre-literacy development. School Psychology Review. 37(1), 74-89.

Attard, C. (2012). Applying a framework for engagement with mathematics in the primary classroom. Australian Primary Mathematics Classroom. Retrieved from http://ezproxy.uws.edu.au/login?url=http://search.informit.com.au/documentSum mary; $\mathrm{dn}=002704336847315 ; \mathrm{res}=$ IELHSS

Blumenfeld, P., Modell, J., Bartko, W. T., Secada, W., Fredricks, J., Friedel, J., et al. (2005).

School engage- ment of inner city students during middle childhood. In C. R. Cooper, C. Garcia Coll, W. T. Bartko, H. M. Davis, \& C. Chatman (Eds.), Developmental pathways through middle childhood: Rethinking diversity and contexts as resources (pp. 145-170). Mahwah, NJ: Lawrence Erlbaum.

Battistich, V., Solomon, D., Watson, M. \& Schaps, E. (1997). Caring school communities. Educational Psychologist, 32, 137-151.

Berk, L.E. (1997). Child development (4th. ed.). Allyn \& Bacon; Boston.

Bhattacherjee, A. (2012), Social Science Research: Principles, Methods, and Practices" (2012). Textbooks Collection. Book 3. http://scholarcommons.usf.edu/ oa textbooks $/ 3$ 
Christenson, S. L. (2004). The family-school partnership: An opportunity to promote the learning competence of all students. School Psychology Review, 33, 83-104.

Connell, J. P. (1990). Context, self, and action: A motiva tional analysis of self-system processes across the life- span. In D. Cicchetti (Ed.), The self in transition: Infancy to childhood (pp. 61-97). Chicago: University of Chicago Press.

Connell, J. P., \& Wellborn, J. G. (1991). Competence, autonomy, and relatedness: A motivational analysis of self-system processes. In M. R. Gunnar \& L. A. Sroufe (Eds.), Self-processes and development: Minnesota symposium on child psychology (pp. 43-77). Chicago: University of Chicago Press.

Dorman, J. P. (2003) Cross national validation of the What Is Happening In this Class questionnaire using confirmatory factor analysis. Learning Environments Research, 6, 231-245

DeVillis, R. F. (2016). Scale development: Theory and applications. Newbury Park, CA: Sage.

Fantuzzo, J., Tighe, E., \& Childs, S. (2000). Family Involvement Questionnaire: A multivariate assessment of family participation in early childhood education. Journal of Educational Psychology 92, 367-376.

Fredricks, J. A., Blumenfeld, P. C., \& Paris, A. H. (2004). School engagement: potential of the concept, state of the evidence. Rev Educ Res, 74(1), 59-109.

Fredricks J, \& McColskey W. (2012). The measurement of student engagement: a comparative analysis of various methods and student self-report instruments. In Christenson SL, Reschly AL, Wylie C, editors. Handbook of research on student engagement (pg 763-82). US: Springer.

Finn, J. D. \& Zimmer, K. S. (2012). Student Engagement: What Is It? Why Does It Matter?, in Handbook of research on student engagement ( $p$ 97-131). S. Christenson, A. L. Reschly and C. Wylie, Eds., Springer,

Furrer, C., \& Skinner, E. (2003). Sense of relatedness as a factor in children's academic engagement and performance. Journal of Educational Psychology, 95, 148-162

Goodenow, C. (1993) The psychological sense of school membership among adolescents: scale development and educational correlates. Psychology in the Schools, 30(1), 79-90.

Gibson, D. M., \& Jefferson, R. N. (2006). The effect of perceived parental involvement and the use of growth-fostering relationships on self-concept in adolescents participating in Gear Up. Adolescence, 41(161), 111-125.

Harris, L. H. (2008), A Phenomenographic Investigation of Teacher Conceptions of Student Engagement in Learning, The Australian Educational Researcher, 5(1), 57-79.

Park, S. Y. (2005). Student engagement and classroom variables in improving mathematics achievement. Asia Pacific Education Review. 6(1), 87-97.

Hogue A, Steinberg L. (1995). Homophily of internalized distress in adolescent peer groups. Dev. Psychol. 31, 897-906

Hamre, B. K., \& Pianta, R. C. (2001). Early teacher-child relationships and the trajectory of children's school outcomes through eighth grade. Child Development, 72(2), 625-638.

Hughes, J. N, Cavell, T. A, \& Willson, V. (2001). Further support for the developmental significance of the quality of the teacher-student relationship. Journal of School Psychology. 39, 289-301. 
Juvonen, J., Espinoza, G., \& Knifsend, C. (2012). The role of peer relationships in student academic and extracurricular engagement. In S. Christenson, A. L. Reschly, \& C. Wylie (Eds.), Handbook of research on student engagement (pp. 387-410). New York: Springer.

Gunuc, S. (2014). The relationships between student engagement and their academic achievement. International Journal on New Trends in Education and Their Implication. 5(4). 1309-6249

Kong, Q., Wong, N., \& Lam, C. (2003). Student engage- ment in mathematics: Development of instrument and validation of a construct. Mathematics Education Research Journal, 54, 4-21.

Krause, K., \& Coates, H. (2008). Students' engagement in first-year University. Assessment \& Evaluation in Higher Education, 33(5), 493-505

Kuh, G. D., Kinzie, J., Buckley, J., Bridges, B., \& Hayek, J. C. (2007). Piecing together the student success puzzle: Research, propositions, and recommendations. ASHE Higher Education Report, 32(5). San Francisco: Jossey-Bass.

Lewis, A. D. (2010). Facilitating student engagement: The importance of life satisfaction. Unpublished doctorate thesis, South Carolina University.

Li, Y., Lerner, J.V. \& Lerner, R.M. (2010). Personal and ecological assets and academic competence in early adolescence: The mediating role of school engagement. Journal of Youth and Adolescence, 39(7), 801-815.

Little, M., \& Kobak, R. (2003) Emotional security with teachers and children's stress reactivity: A comparison of special-education and regular-education classrooms. Journal of Clinical Child and Adolescent Psychology. 32(1), 127-138.

Martin, A. J., \& Marsh, H. W. (2009). Academic resilience and academic buoyancy: Multidimensional and hierarchical conceptual framing of causes, correlates and cognate constructs. Oxford Review of Education, 35, 353-370.

Ridley, S. M., McWilliam, R. A., \& Oates, C. S. (2000). Observed engagement as an indicator of child care program quality. Early Education and Development, 11, 133-146.

Morse, A., Anderson, A., Christenson, S., \& Lehr, C. (2004). Promoting school completion. Principal Leadership Magazine, 4(5), 9-13

Newmann, F., Wehlage, G. G., \& Lamborn, S. D. (1992). The significance and sources of student engagement. In F. Newmann (Ed.), Student engagement and achievement in American secondary schools (pp. 11-39). New York: Teachers College Press.

Oyserman, D., Brickman, D., \& Rhodes, M. (2007). School success, possible selves, and parent school involvement. Family Relations, 56, 479-489

Pianta, R. C, \& Stuhlman, M. W. (2004). Conceptualizing risk in relational terms: Associations among the quality of child-adult relationships prior to school entry and children's developmental outcomes in first grade. Educational and Child Psychology Special Issue: At-Risk Children From Birth to Elementary School Age: Research Findings and Reflections on Intervention from an International Perspective. 21(1), 32-45.

Skinner, E. A., \& Belmont, M. J. (1993). Motivation in the classroom: reciprocal effect of teacher behavior and student engagement across the school year. $J E d u c$ Psychol, 85, 571-581. 
Steinberg, L. D., Brown, B. B., \& Dornbush, S. M. (1996). Beyond the classroom: Why school reform has failed and what parents need to do. New York: Simon and Schuster.

Tas, Y. (2016) The contribution of perceived classroom learning environment and motivation to student engagement in science. Eur J Psychol Educ. 2016(31), 557577

Veiga, F. H., Carvalho, C., Almeida, A., Taveira, C., Janeiro, I., Baía, S., Festas, I., Nogueira, J.,

Melo, M., \& Caldeira, S. (2012). Students' engagement in schools: differentiation and promotion In M. F. Patrício, L. Sebastião, J. M. Justo, \& J. Bonito (Eds.), Da Exclusão à Excelência: Caminhos Organizacionais para a Qualidade da Educação (pp. 117-123). Montargil: Associação da Educação Pluridimensional e da Escola Cultural.

Wang, M.T. \& Eccles, J. (2012). Social Support Matters: Longitudinal Effects of Social Support on Three Dimensions of School Engagement From Middle to High School. Child Development, 83, 877-895.

Wang, M. T., \& Holcombe, R. (2010). Adolescents' perceptions of school environment, engagement, and academic achievement in middle school. American Educational Research Journal, 47, 633- 662.

Willms, J. D. (2003) Student Engagement at School: A Sense of Belonging and Participation, OECD Publishing, accessed 17 April 2013, from http://www.oecd. org/education/school/programmeforinternationalstudentassessmentpisa/3368 9437.pdf 